\title{
Organic anion-transporting polypeptides contribute to the uptake of curcumin and its main metabolites by human breast cancer cells: Impact on antitumor activity
}

\author{
NATTHARAT JAERAPONG ${ }^{1,2}$, QURRATUL AIN JAMIL ${ }^{1}$, JULIANE RIHA ${ }^{1}$, DANIELA MILOVANOVIC ${ }^{3}$, \\ GEORG KRUPITZA $^{3}$, BRUNO STIEGER ${ }^{4}$, KANOKWAN JARUKOMJORN ${ }^{2}$ and WALTER JÄGER ${ }^{1}$ \\ ${ }^{1}$ Department of Clinical Pharmacy and Diagnostics, University of Vienna, A-1090 Vienna, Austria; \\ ${ }^{2}$ Research Group for Pharmaceutical Activities of Natural Products using Pharmaceutical Biotechnology (PANPB), \\ Faculty of Pharmaceutical Sciences, Khon Kean University, Khon Kaen 40002, Thailand; \\ ${ }^{3}$ Department of Clinical Pathology, Medical University of Vienna, Vienna A-1090, Austria; \\ ${ }^{4}$ Department of Clinical Pharmacology and Toxicology, University Hospital Zurich, 8091 Zurich, Switzerland
}

Received August 31, 2018; Accepted February 11, 2019

DOI: 10.3892/or.2019.7011

\begin{abstract}
Curcumin is a natural polyphenolic compound with pronounced anticancer properties, despite its low bioavailability caused by extensive glucuronidation and sulfation. Information on the cellular uptake mechanisms and their contribution to the anticancer effects of curcumin and its biotransformation products is limited. The present study, therefore, investigated the role of organic anion-transporting polypeptides (OATPs) in the cellular uptake of curcumin and its major metabolites in OATP-expressing Chinese hamster ovary (CHO) and human ZR-75-1 breast cancer cells. The uptake rates for curcumin in OATP1B1-, OATP1B3- and OATP2B1-transfected CHO cells were 2- to 3-fold higher than wild-type cells. Curcumin sulfate was transported by all three OATPs, although to a much lesser extent, while uptake of tetrahydrocurcumin was the highest but only via OATP1B1 and OATP1B3. Notably, curcumin glucuronide did not exhibit any affinity for these OATPs. The increased mRNA levels of OATP1B1 in wild-type human breast cancer ZR-75-1 cells compared with OATP1B1 knockdown cells was associated with a higher initial uptake of curcumin and tetrahydrocurcumin leading to decreased $\mathrm{IC}_{50}$ values. In conclusion, our data revealed that OATPs act as cellular uptake transporters for curcumin and its major metabolites, and this may also be applicable to patients undergoing cancer therapy.
\end{abstract}

Correspondence to: Professor Walter Jäger, Department of Clinical Pharmacy and Diagnostics, University of Vienna, Althanstrasse 14, A-1090 Vienna, Austria

E-mail: walter.jaeger@univie.ac.at

Key words: curcumin, metabolism, breast cancer, OATP, transport, cytotoxicity

\section{Introduction}

Breast cancer is the most common type of invasive cancer in women and the second main cause of cancer mortality in females, following lung cancer. Chemoprevention in combination with anticancer treatment is therefore important to reduce incidence and mortality rates. Epidemiological and experimental studies have demonstrated that natural nutritional compounds are potent chemopreventive agents against mammary carcinogenesis $(1,2)$. One of these food constituents is Curcuma, a yellowish-orange polyphenol from the rhizome of Curcuma longa. Since ancient times, it has been used as herbal therapy in China and India against numerous diseases (3). Curcumin is also an anticancer agent, as recently revealed in a mouse xenograft breast cancer model, where it significantly prevented tumor growth and angiogenesis (4). In hormone-dependent and independent human breast cancer cells, curcumin interferes with apoptosis by regulating STAT3, NF- $\mathrm{B}$, AP-1, HER2, CXCR4, EGFR, ERK, $\alpha \mathrm{JAK}, \mathrm{TNF}, \mathrm{IL}$ and MP activity (5-7). Curcumin attenuates the expression of matrix metalloproteinases (MMPs) via reduced activity of NF- $\mathrm{B}$ and transcriptional downregulation of AP-1 (8), thereby decreasing the number of lung metastases in mice upon intracardiac injection of estrogen receptor-negative human breast cancer MDA-MB-231 cells (8). Curcumin exhibited a synergistic effect with paclitaxel against human MCF-7 and MDA-MB-231 cells (9). Furthermore, curcumin demonstrated better clinical responses also in a phase-I clinical trial with docetaxel in patients with prolonged and metastatic breast cancer (10). Notably, despite its activity against breast cancer cells, curcumin exerts little toxicity against normal cells, even upon long-term exposure.

Previous studies in mice and rats demonstrated extensive metabolism of curcumin in the small intestine and liver mainly to curcumin sulfate, curcumin glucuronide and tetrahydrocurcumin (11). Biotransformation of curcumin is also extensive in humans, as shown in a pilot study of a standardized Curcuma-derived extract in patients with colorectal 
cancer (12). In addition to the formation of curcumin glucuronide and curcumin sulfate, curcumin undergoes phase-I bioreduction mainly to tetrahydrocurcumin and to a minor part to hexahydrocurcumin, octahydrocurcumin and hexahydrocurcuminol $(13,14)$, which are subsequently further conjugated to glucuronides and sulfates (13). Biotransformation is cell-specific, as a recent study from our laboratory revealed that in hormone-dependent ZR-75-1 and hormone-independent MDA-MB-231 breast cancer cells the main metabolite was curcumin sulfate, while curcumin glucuronide formation was below the detection limit (15). Intracellular curcumin sulfate was subsequently discharged released into the cellular medium, leading to $<12$-fold higher concentrations compared with the cytoplasm indicating an active efflux mechanism. A possible candidate for this efflux is the breast cancer resistance protein (BCRP and ABCG2), which is expressed in numerous tissues, including breast ductal cells, and serves an important role in the efflux of sulfated conjugates of steroids and drugs (16). An interplay of curcumin with BCRP has already been described and may also apply to its sulfated metabolite (17).

Currently, limited information is available about the activities of curcumin biotransformation products. Previous in vitro data suggest that the main metabolites of curcumin, i.e. curcumin sulfate and curcumin glucuronide are less potent than curcumin against various tumor cell lines. In vivo, however, curcumin conjugates may markedly contribute to the pharmacological activity of curcumin, since ubiquitously expressed sulfatases or $\beta$-glucuronidases may rapidly cleave the conjugates back into curcumin. However, tetrahydrocurcumin, a major metabolite of curcumin, has demonstrated similar anticancer activities to curcumin. In $\mathrm{H} 22$ ascites hepatocarcinoma tumor-bearing mice and in an animal carcinogenesis model tetrahydrocurcumin was even more effective than curcumin $(18,19)$. Moreover, intragastric treatments of tetrahydrocurcumin $(40 \mathrm{mg} / \mathrm{kg})$ to mice were more effective than curcumin $(100 \mathrm{mg} / \mathrm{kg})$ in inhibiting the expression of cyclooxygenase-2 and suppressing NF- $\mathrm{B}$ (20). Unlike curcumin, tetrahydrocurcumin is stable in $0.1 \mathrm{M}$ phosphate buffer at $\mathrm{pH} 7.2$ and in plasma (21), and may therefore significantly contribute to the anticancer activity of curcumin.

Active uptake mechanisms into the cytoplasm of tumor cells may be more significant than metabolism for the efficiency of curcumin. One of the main membrane transport proteins are organic-anion-transporting polypeptides (OATPs), which mediate the uptake of numerous clinically used drugs and natural compounds such as polyphenols and their sulfates (22-26). The strongest effect on bioavailability is due to OATP2B1, which is highly expressed in the intestine, and to OATP1B1 and OATP1B3, which are expressed in the liver. Various OATPs are also highly expressed in human hormone receptor-positive (MCF-7) and negative (MDA-MB-231) breast cancer cell lines (27). Zhou et al recently demonstrated that curcumin is a substrate of OATP1B1, OATP1B3 and OATP2B1, and that curcumin glucuronide is a substrate of OATP1B1 and OATP1B3 but not of OATP2B1, using OATP-transfected 293 cells (28). Additional experiments by the same authors (28) and by Sun et al (29) revealed that curcumin and curcumin glucuronide are also inhibitors of the OATP1B1 and 1B3 substrates rosuvastatin and docetaxel. However, no data are available to date on whether curcumin sulfate and tetrahydrocurcumin are also transported by OATPs. The present study therefore investigated the time and concentration-dependent transport of curcumin, curcumin sulfate, curcumin glucuronide and tetrahydrocurcumin in Chinese hamster ovary (CHO) cells stably-transfected with OATP1B1, OATP1B3 and OATP2B1. Furthermore, the kinetics of the uptake of curcumin and its main metabolites was calculated in order to determine the affinity of each substrate for the three transporters. Finally, the importance of OATPs in the anticancer activity of curcumin and tetrahydrocurcumin was elucidated in wild-type and OATP1B1-knockdown human breast cancer cell line ZR-75-1, and any differences in cellular uptake associated with cytotoxicity were evaluated.

\section{Materials and methods}

Materials. Curcumin (98\% pure) and tetrahydrocurcumin (95\% pure) were purchased from Sigma-Aldrich (Merck KGaA, Darmstadt, Germany). Curcumin sulfate and curcumin glucuronide were obtained from TLC Pharmaceutical Standards Ltd. (Aurora, ON, Canada). Methanol and water were of high-performance liquid chromatography (HPLC) grade (Merck KGaA). All other chemicals and solvents were commercially available and of analytical grade, and were used without further purification.

Cell culture. Chinese hamster ovary $(\mathrm{CHO})$ cells that were stably transfected with OATP1B1, OATP1B3 and OATP2B1, as well as wild-type $\mathrm{CHO}$ cells, were provided by the Department of Clinical Pharmacology and Toxicology, University Hospital Zurich (Zurich, Switzerland). These cells have been extensively characterized previously $(30,31)$. The $\mathrm{CHO}$ cells were grown in Dulbecco's modified Eagle's medium (DMEM) supplemented with $10 \%$ fetal calf serum (FCS), $50 \mu \mathrm{g} / \mathrm{ml}$ L-proline, $100 \mathrm{U} / \mathrm{ml}$ penicillin and $100 \mu \mathrm{g} / \mathrm{ml}$ streptomycin (Life Technologies; Thermo Fisher Scientific, Inc., Waltham MA, USA). The selection medium for stably transfected CHO cells additionally contained $500 \mu \mathrm{g} / \mathrm{ml}$ geneticin sulfate (G418) (32). All of the media and supplements were obtained from Life Technologies (Thermo Fisher Scientific, Inc.). The mammalian ZR-75-1 breast cancer cell line was purchased from the American Type Culture Collection (ATCC; Manassas, VA, USA) and was maintained in RPMI-1640 medium (Life Technologies; Thermo Fisher Scientific, Inc.) supplemented with $10 \% \mathrm{FCS}, 100 \mathrm{U} / \mathrm{ml}$ penicillin, $100 \mu \mathrm{g} / \mathrm{ml}$ streptomycin and 1\% GlutaMAX (Life Technologies; Thermo Fisher Scientific, Inc.). The cells were grown in T-flasks with a $25-\mathrm{cm}^{2}$ growth area (BD Biosciences, Franklin Lakes, NJ, USA) and maintained at $37^{\circ} \mathrm{C}$ under $5 \% \mathrm{CO}_{2}$ and $95 \%$ relative humidity. The cells were passaged once per week and were used at passages $\leq 55$ (24).

OATPIB1 knockdown in ZR-75-1 cells. For lentiviral transduction, ZR-75-1 cells were plated in 24-well tissue culture plates at a density of 40,000 cells/well in $0.5 \mathrm{ml}$ of growth medium. After $24 \mathrm{~h}, 250 \mu \mathrm{l}$ of medium supplemented with $8 \mu \mathrm{g} / \mathrm{ml}$ polybrene (Sigma-Aldrich; Merck KGaA) was added. Transductions were performed by the addition of $10 \mu \mathrm{l}$ of shRNA (Mission ${ }^{\circledR}$ Transduction Particles NM_006446; Sigma-Aldrich; Merck KGaA), and the TRCN0000043203 coding sequence was as 
follows: 5'-CCGGGCCTTCATCTAAGGCTAACATCTCGA GATGTTAGCCTTAGATGAAGGCTTTTTG-3'. At $24 \mathrm{~h}$ post-transduction, the cell culture medium was changed, and $1 \mathrm{ml}$ of growth medium supplemented with 1 or $5 \mu \mathrm{g} / \mathrm{ml}$ puromycin (Sigma-Aldrich; Merck KGaA) was added to select cells after an additional $24 \mathrm{~h}$. The obtained silencing efficiency was evaluated after 3 weeks via reverse transcription-quantitative polymerase chain reaction (RT-qPCR).

$R T-q P C R$. Total RNA was extracted from cells using TRIzol reagent (Invitrogen; Thermo Fisher Scientific, Inc.) according to the manufacturer's instructions as previously described (28). $\mathrm{TaqMan}^{\circledR}$ Gene Expression assays (Applied iosystems; Thermo Fisher Scientific, Inc.) were applied for human OATP1B1 detection. The $18 \mathrm{~S}$ gene was used as a reference gene as previously described (27). Multiplex RT-qPCR was performed in an amplification mixture (25 $\mu \mathrm{l}$ ) containing $10 \mu \mathrm{l}$ of $2 \mathrm{X}$ TaqMan ${ }^{\circledR}$ Universal PCR Master Mix, $1 \mu l$ appropriate Gene Expression assay, $1 \mu \mathrm{l} \mathrm{TaqMan}{ }^{\circledR}$ endogenous control (human $\beta$-actin or $18 \mathrm{~S}), 10 \mathrm{ng}$ template complementary DNA (cDNA) diluted in $3 \mu \mathrm{l}$ nuclease-free water. The thermal cycling conditions were as previously described (33). Fluorescence generation due to the cleavage of the TaqMan ${ }^{\circledR}$ probe via the $5^{\prime} \rightarrow 3^{\prime}$ exonuclease activity of the DNA polymerase was detected with an ABI PRISM 7700 Sequence Detection System (Applied Bioystems; Thermo Fisher Scientific, Inc.). All samples were amplified in triplicate. To cover the range of expected quantitative cycle (Cq)-values for the target mRNA (34), a standard curve of 6 serial dilutions from $50 \mathrm{ng}$ to $500 \mathrm{pg}$ pooled cDNA was analyzed using Sequence Detection software 1.9.1. (Applied iosystems; Thermo Fisher Scientific, Inc.). Relative gene expression data are given as the n-fold change in transcription of target genes normalized to the endogenous control. Real-time RT-PCR was performed with the following prefabricated TaqMan ${ }^{\circledR}$ Gene Expression assays (Applied iosystems; Thermo Fisher Scientific, Inc.) which contained the intron-spanning primer Hs00272374_m1 for OATP1B1.

Cellular uptake. Transport assays were performed on 12-well plates as previously described (33). Briefly, OATP-transfected CHO cells were seeded at a density of 350,000 cells/well on 12-well plates (BD Biosciences). Uptake assays were generally performed on day 3 after seeding when the cells had grown to confluence. After $24 \mathrm{~h}$ of initiation before starting the transport experiments, cells were treated with $5 \mathrm{mM}$ sodium butyrate (Sigma-Aldrich; Merck KGaA) to induce non-specific gene expression (35). Curcumin and its metabolites were dissolved in dimethyl sulfoxide (DMSO) and diluted in uptake buffer ( $\mathrm{pH}$ 7.4; final DMSO concentration of $0.5 \%$ ) to $25-600 \mu \mathrm{M}$. Control experiments contained DMSO in the medium instead of curcumin and its biotransformation products, respectively. Prior to the transport experiment, cells were rinsed twice with $2 \mathrm{ml}$ of pre-warmed $\left(37^{\circ} \mathrm{C}\right)$ uptake buffer $(116.4 \mathrm{mM} \mathrm{NaCl}, 5.3$ $\mathrm{mM} \mathrm{KCl}, 1 \mathrm{mM} \mathrm{NaH}_{2} \mathrm{PO}_{4}, 0.8 \mathrm{mM} \mathrm{MgSO}_{4}, 5.5 \mathrm{mM}$ D-glucose and $20 \mathrm{mM}$ HEPES; $\mathrm{pH}$ adjusted to 7.4). Uptake at $37^{\circ} \mathrm{C}$ was initiated by adding $0.25 \mathrm{ml}$ of uptake buffer containing the substrate. After $1 \mathrm{~min}$, the uptake was stopped, and the cells were washed 5 times with $2 \mathrm{ml}$ of buffer ( $\mathrm{pH}$ 7.4) and subsequently trypsinized by the addition of $100 \mu 1$ of trypsin. Cell membranes were then disrupted via repeated (5 times) shock freezing in liquid nitrogen and thawing. Following centrifugation at $13,500 \mathrm{x}$ g for $5 \mathrm{~min}, 100 \mu \mathrm{l}$ supernatant was diluted with methanol/water $(2: 1 ; \mathrm{v} / \mathrm{v})$ and aliquots $(80 \mu \mathrm{l})$ were analyzed via HPLC. All experiments were repeated at least 3 times.

Transport of curcumin and tetrahydrocurcumin in wild-type ZR-75-1 and OATPIB1-knockdown ZR-75-1 cells. Cells were plated on 6-well plates and allowed to attach overnight. Cells were then incubated for $1 \mathrm{~min}$ at $37^{\circ} \mathrm{C}$ with curcumin and tetrahydrocurcumin (25-200 $\mu \mathrm{M}$; final DMSO concentration $<0.5 \%$ ). Control experiments contained DMSO in the medium in place of curcumin and tetrahydrocurcumin. Then uptake was stopped, and the cells were washed 5 times with $2 \mathrm{ml}$ phosphate-buffered saline (PBS) and subsequently trypsinized by the addition of $100 \mu 1$ trypsin. Cell membranes were lysed by repeated (5 times) shock freezing in liquid nitrogen and thawing. Following centrifugation at $13,500 \mathrm{x} g$ for $5 \mathrm{~min}, 80$ $\mu \mathrm{l}$ supernatant (cytoplasm) was analyzed by HPLC for detection of curcumin and tetrahydrocurcumin. All experiments were repeated at least 3 times.

Cytotoxicity assay. ZR-75-1 wild-type and OATP-knockdown cells $(50,000$ cells $/ \mathrm{ml})$ were seeded into 96 -well plates and incubated for $24 \mathrm{~h}$ at $37^{\circ} \mathrm{C}$ under $5 \% \mathrm{CO}_{2}$. Then, cells were incubated with various concentrations of curcumin (2.5-100 $\mu \mathrm{M})$ for $72 \mathrm{~h}$, the incubation stopped and CellTiter-Blue reagent (Promega Corp., Madison, WI, USA) (20 $\mu$ l) was added to the wells. The plates were then incubated for $2 \mathrm{~h}$ at $37^{\circ} \mathrm{C}$ and the absorbance was recorded for resazurin $(605 \mathrm{~nm})$ and resorufin $(573 \mathrm{~nm})$ on a Tecan M200 multimode plate reader (Tecan Group, Ltd., Männedorf, Switzerland). The viability of the treated cells was expressed as a percentage of the viability of the corresponding control cells. All experiments were repeated at least 3 times.

Determination of protein concentrations. Total protein was determined using the BCA assay kit (Pierce; Thermo Fisher Scientific, Inc.) with bovine serum albumin (BSA) as a standard and quantification at a wavelength of $562 \mathrm{~nm}$ on a spectrophotometer (UV-1800; Shimadzu Corp., Kyoto, Japan). Raw data were analyzed using UV-Probe version 2.31 software (Shimadzu Corp.). The protein concentrations were consistent among the plates $(0.150 \pm 0.005 \mathrm{mg} / \mathrm{well})$.

HPLC analysis. The concentrations of curcumin and its biotransformation products were quantified by HPLC using the same Dionex UltiMate 3000 system (Dionex Corp., Sunnyvale, CA, USA), column, mobile phase and gradient as previously described (15). Calibration of the chromatogram was accomplished using the external standard method. Linear calibration curves were performed by spiking drug-free cell culture medium with standard solutions of curcumin, curcumin sulfate, curcumin glucuronide, and tetrahydrocurcumin to produce a concentration range from 0.01 to $10 \mu \mathrm{g} / \mathrm{ml}$ (average correlation coefficients: $>0.999$ ). Coefficients of accuracy and precision for these compounds were $<11 \%$.

$N F-\kappa B$-luciferase reporter assay. A total of 100,000 ZR-75-1 wild-type and OATP1B1-knockdown ZR-75-1 cells were 
seeded in 24-well plates and grown to $70 \%$ confluency for transfection. Simultaneous transfection with pTAL-NF- $\mathrm{B}$ $(\mathrm{NF}-\kappa \mathrm{B}$ response element-Firefly luciferase reporter; Clontech Laboratories, Inc., Mountainview, CA, USA) and pRL-TK (Control-Renilla luciferase; Promega Corp.) was performed with Lipofectamine 2000 (Life Technologies; Thermo Fisher Scientific, Inc.; cat. no. 11668) according to the manufacturer's protocol. NF- $\kappa \mathrm{B}$ was blocked for $30 \mathrm{~min}$ with 10 $\mu \mathrm{M}$ BAY11-7082 (Calbiochem; Merck KGaA) or $100 \mu \mathrm{M}$ curcumin, respectively. Then, $10 \mathrm{ng} / \mathrm{ml}$ interleukin $1 \beta$ (IL-1 $\beta$; Sigma-Aldrich; Merck KGaA) was added and incubated for $90 \mathrm{~min}$ at $37^{\circ} \mathrm{C}$, immediately followed by luciferase assay (Promega Corp.; cat. no. E1910). Briefly, cells were lysed with lysis buffer, the first substrate to detect the firefly luciferase was added, and the samples were immediately measured for 6 sec. Upon addition of the second substrate signals for Renilla luciferase were assessed.

Data and statistical analysis. Kinetic parameters were calculated using the GraphPad Prism version 6.0 software program (GraphPad Software, Inc., La Jolla, CA, USA) for a Michaelis-Menten kinetic model: $\mathrm{V}=\mathrm{V}_{\max } \times \mathrm{S} /\left(\mathrm{K}_{\mathrm{m}}+\mathrm{S}\right)$, where $\mathrm{V}$ is the rate of the reaction; $\mathrm{V}_{\max }$ is the maximum velocity; $\mathrm{K}_{\mathrm{m}}$ is the Michaelis constant and $\mathrm{S}$ is the substrate concentration. The intrinsic clearance, which is defined as the ratio $\mathrm{V}_{\max } / \mathrm{K}_{\mathrm{m}}$, quantifies the transport capacity. $\mathrm{IC}_{50}$ values of curcumin and tetrahydrocurcumin cytotoxicity against wild-type and OATP-knockdown ZR-75-1 cells were calculated by fitting a non-linear model to cell viability vs. (log)concentrations data using the GraphPad Prism version 6.0 software (GraphPad Software, Inc.). This software was also used for all statistical analyses. All values were expressed as the mean \pm standard deviation (SD) of 3 independent biological replicates and one-way analysis of variance (ANOVA) followed by Tukey's post hoc test was used to compare differences between the wild-type and OATP1B1-knockdown ZR-75-1 cells. The statistical significance threshold was defined as $\mathrm{P}<0.05$ for all calculations.

\section{Results}

Accumulation of curcumin and its metabolites in transfected $\mathrm{CHO}$ cells. To investigate whether curcumin and its major conjugates are substrates of OATPs, uptake analyses were performed in OATP1B1-, OATP1B3- and OATP2B1-transfected CHO cells. CHO cells only transfected with the vector were used as controls. The uptake of curcumin (25-200 $\mu \mathrm{M})$ by all three OATPs was linear for up to $1 \mathrm{~min}$ (data not shown). As revealed in Table I and Fig. 1, the initial OATP1B1-, OATP1B3- and OATP2B1-mediated accumulation rates (namely, OATP-transfected $\mathrm{CHO}$ cells minus $\mathrm{CHO}$ cells only transfected with the vector) for curcumin followed Michaelis-Menten kinetics, with higher $\mathrm{V}_{\max }$ values for OATP1B1 than for OATP1B3 and OATP2B1 ( $\mathrm{V}_{\max }, 310 \mathrm{vs} .205$ and $167 \mathrm{pmol} / \mathrm{mg}$ protein/min, respectively). The $\mathrm{K}_{\mathrm{m}}$-values were similar for all three OATPs (range, 46.9-51.9 $\mu \mathrm{M}$ ). The uptake of curcumin sulfate $(25-300 \mu \mathrm{M})$ in OATP1B1-, OATP1B3- and OATP2B1-transfected CHO cells, was less pronounced, revealing $\mathrm{V}_{\max }$ values of only 45.0, 33.9 and 24.3 $\mathrm{pmol} / \mathrm{mg}$ protein/min, respectively (Table I and Fig. 2). Its
Table I. Michaelis-Menten parameters for the uptake of curcumin, curcumin sulfate, tetrahydrocurcumin and curcumin glucuronide in OATP-transfected CHO cells.

\begin{tabular}{lccc}
\hline Substrate & $\mathrm{K}_{\mathrm{m}}[\mu \mathrm{M}]$ & $\begin{array}{c}\mathrm{V}_{\text {max }} \\
{[\mathrm{pmol} / \mathrm{mg} / \mathrm{min}]}\end{array}$ & $\begin{array}{c}\mathrm{V}_{\text {max }} / \mathrm{K}_{\mathrm{m}} \\
{[\mu \mathrm{l} / \mathrm{min} . \mu \mathrm{g}]}\end{array}$ \\
\hline OATP1B1 & & & \\
Cur & $51.9 \pm 13.6$ & $167 \pm 14.8$ & $3.21 \pm 0.64$ \\
Cur-S & $89.1 \pm 16.4$ & $45.0 \pm 3.34$ & $0.51 \pm 0.06$ \\
TH-cur & $38.6 \pm 7.9$ & $872 \pm 35.6$ & $22.6 \pm 3.86$ \\
Cur-G & n.d. & n.d. & n.d. \\
OATP1B3 & & & \\
Cur & $46.9 \pm 7.5$ & $205 \pm 10.7$ & $4.37 \pm 0.48$ \\
Cur-S & $67.7 \pm 15.3$ & $33.9 \pm 2.76$ & $0.50 \pm 0.076$ \\
TH-cur & $83.7 \pm 13.4$ & $493 \pm 22.5$ & $5.89 \pm 0.69$ \\
Cur-G & n.d. & n.d. & n.d. \\
OATP2B1 & & & \\
Cur & $48.6 \pm 12.7$ & $310 \pm 26.6$ & $6.37 \pm 1.27$ \\
Cur-S & $50.0 \pm 12.6$ & $24.3 \pm 1.87$ & $0.48 \pm 0.102$ \\
TH-cur & n.d. & n.d. & n.d. \\
Cur-G & n.d. & n.d. & n.d. \\
\hline
\end{tabular}

Values are presented as the means \pm SE of 3 individual determinations. The net OATP-mediated uptake values were calculated by subtracting the values obtained with the wild-type $\mathrm{CHO}$ cells from those obtained with the stably-transfected cells. Kinetic parameters were calculated by fitting the data to the Michaelis-Menten $\left(\mathrm{K}_{\mathrm{m}}\right)$ equation with non-linear regression. OATP, organic anion-transporting polypeptide; $\mathrm{CHO}$, Chinese hamster ovary; Cur, curcumin; Cur-S, curcumin sulfate; TH-cur, tetrahydrocurcumin; Cur-G, curcumin glucuronide; n.d., not determined.

affinity, for OATP1B1 and OATP1B3, but not for OATP2B1, was 1.9 and 1.4-fold higher with $\mathrm{K}_{\mathrm{m}}$ values of $89.1 \mu \mathrm{M}$ and $67.7 \mu \mathrm{M}$ compared with curcumin. Tetrahydrocurcumin was taken up by OATP1B1 and OATP1B3 with the highest $\mathrm{V}_{\max }$ values (872 and $493 \mathrm{pmol} / \mathrm{mg}$ protein/min, respectively); $\mathrm{K}_{\mathrm{m}}$ values were 38.6 and $83.7 \mu \mathrm{M}$, respectively (Table I and Fig. 3). Notably, curcumin glucuronide was not a substrate for any of the three OATPs as its levels inside the cytoplasm were below the detection limit.

OATP1B1-knockdown in ZR-75-1 cells. PCR data from various lentiviral-transfected clones revealed an up to 10 -fold reduction in OATP1B1 expression in ZR-75-1-cells (relative mRNA expression was reduced from $14.78 \pm 0.26$ to $1.19 \pm 0.02$ ). Cells with the lowest OATP1B1 expression levels were used for further uptake experiments (27).

Curcumin and tetrahydrocurcumin accumulation in wild-type and OATP1B1-knockdown ZR-75-1 cells. Based on the markedly higher OATP1B1 mRNA level noticed in wild-type ZR-75-1 cells compared with the OATP1B1-knockdown clone and the fact that ZR-75-1 cells do not express OATP1B3 or OATP2B1, uptake of curcumin and tetrahydrocurcumin by wild-type cells was expected to be increased. The results 


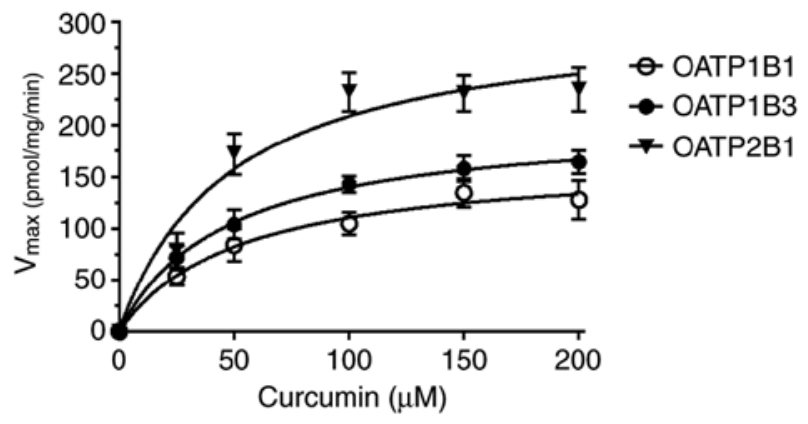

Figure 1. Concentration dependence of curcumin uptake in OATP1B1-, OATP1B3- and OATP2B1-transfected CHO cells. A total of 350,000 cells were seeded in 12-well plates and allowed to grow to confluence. Then the cells were incubated with curcumin $(25-200 \mu \mathrm{M})$ for $1 \mathrm{~min}$ at $\mathrm{pH} 7.4,37^{\circ} \mathrm{C}$ and the cytoplasm was analyzed for curcumin by HPLC. The data represent the mean \pm SD of 3 individual determinations. OATP, organic anion-transporting polypeptide; $\mathrm{CHO}$, Chinese hamster ovary; HPLC, high-performance liquid chromatography.

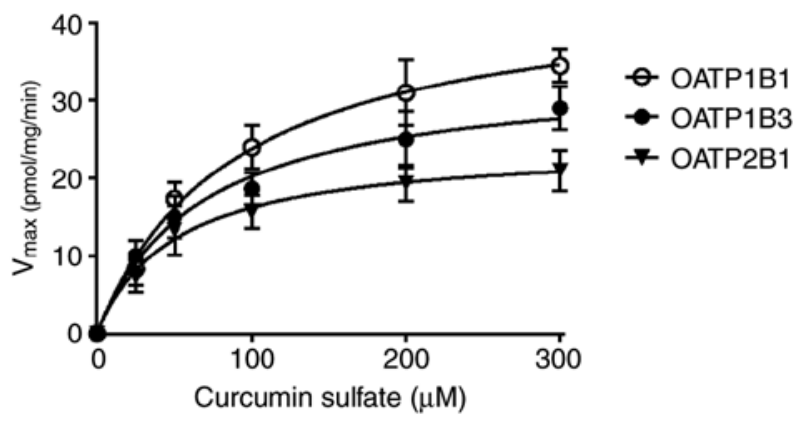

Figure 2. Concentration dependence of curcumin sulfate uptake in OATP1B1OATP1B3- and OATP2B1-transfected CHO cells. A total of 350,000 cells were seeded in 12-well plates and allowed to grow to confluence. Then the cells were incubated with curcumin sulfate $(25-300 \mu \mathrm{M})$ for $1 \mathrm{~min}$ at $\mathrm{pH}$ $7.4\left(37^{\circ} \mathrm{C}\right)$ and the cytoplasm was analyzed for curcumin sulfate by HPLC The data represent the mean \pm SD of 3 individual determinations. OATP, organic anion-transporting polypeptide; $\mathrm{CHO}$, Chinese hamster ovary; HPLC, high-performance liquid chromatography.

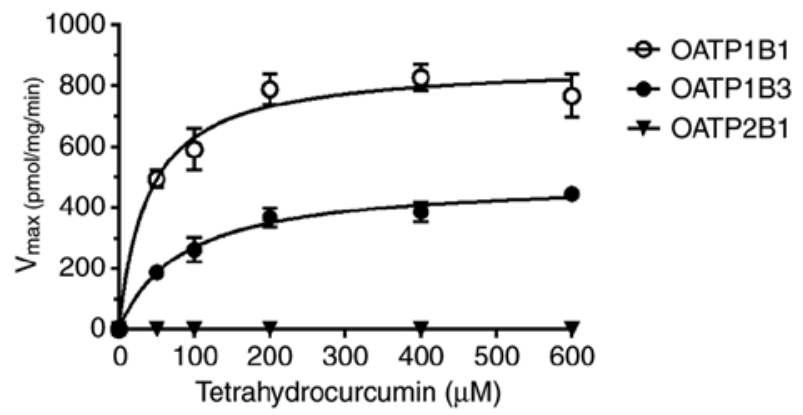

Figure 3. Concentration dependence tetrahydrocurcumin uptake in OATP1B1-, OATP1B3- and OATP2B1-transfected CHO cells. A total of 350,000 cells were seeded in 12-well plates and allowed to grow to confluence. Then the cells were incubated with tetrahydrocurcumin $(50-600 \mu \mathrm{M})$ for $1 \mathrm{~min}$ at $\mathrm{pH}$ $7.4\left(37^{\circ} \mathrm{C}\right)$ and the cytoplasm was analyzed for tetrahydrocurcumin by HPLC The data represent the mean \pm SD of 3 individual determinations. OATP, organic anion-transporting polypeptide; $\mathrm{CHO}$, Chinese hamster ovary; HPLC, high-performance liquid chromatography.

revealed that uptake of curcumin by ZR-75-1 cells was increased as indicated by 2 -fold higher $\mathrm{V}_{\max }$ values compared
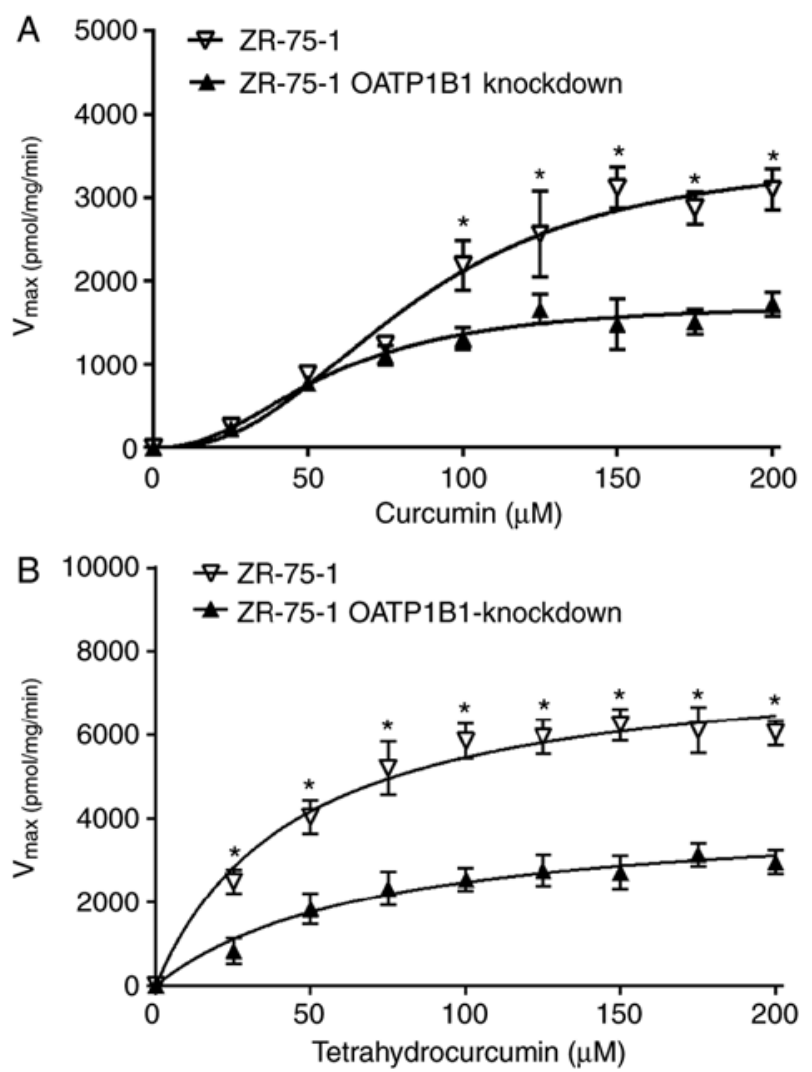

Figure 4. Concentration-dependent uptake rates of (A) curcumin and (B) terahydrocurcumin in ZR-75-1 empty vector-transfected cells compared to ZR-75-1 OATP1B1-knockdown cells. A total of $1 \times 10^{6}$ cells were seeded in 6 -well plates and allowed to grow to confluence. Then, the cells were incubated with curcumin $(25-200 \mu \mathrm{M})$ for $1 \mathrm{~min}$ at $37^{\circ} \mathrm{C}$ and the cytoplasm was analyzed for curcumin by HPLC. The data represent the mean \pm SD of 3 individual determinations. Intracellular concentrations marked with an asterisk denote statistically significant differences $\left({ }^{*} \mathrm{P}<0.05\right)$ between wild-type and OATP1B1-knockdown ZR-75-1 cells. OATP, organic anion-transporting polypeptide; HPLC, high-performance liquid chromatography.

with OATP1B1-knockdown cells $\left(\mathrm{V}_{\max }, 3535\right.$ vs. $1741 \mathrm{pmol} / \mathrm{mg}$ protein/min); the $\mathrm{K}_{\mathrm{m}}$-values only changed slightly $\left(\mathrm{K}_{\mathrm{m}}, 85.1\right.$ vs. $56.7 \mu \mathrm{M}$ ) (Fig. 4A and Table II). Differences in the uptake of tetrahydrocurcumin were also pronounced leading to 2-fold higher $\mathrm{V}_{\max }$ values in wild-type cells compared with the OATP1B1-knockdown clone $\left(\mathrm{V}_{\max }, 7904\right.$ vs. $4201 \mathrm{pmol} / \mathrm{mg}$ protein/min); the $\mathrm{K}_{\mathrm{m}}$-values were significantly reduced in the wild-type cells $\left(\mathrm{K}_{\mathrm{m}}, 44.7\right.$ vs. $\left.69.6 \mu \mathrm{M}\right)$ (Fig. 4B and Table II) supporting the impact of OATP1B1 for curcumin and tetrahydrocurcumin transport. Notably, any interference in curcumin and tetrahydrocurcumin uptake with efflux mechanisms (e.g. BCRP) could be excluded as the incubation time was only 1 $\min$.

Cytotoxicity of curcumin in ZR-75-1 OATP1B1-knockdown cells. As revealed in Fig. 5A, curcumin exhibited a lower $\mathrm{IC}_{50}$ value in wild-type ZR-75-1 cells $(12.4 \mu \mathrm{M})$ compared with the OATP1B1 knockdown clone $(15.2 \mu \mathrm{M})$, although the differences were not significant. The $\mathrm{IC}_{50}$ value for tetrahydrocurcumin, however, was significantly lower in OATP1B1 expressing cells $(26.0$ vs. $51.3 \mu \mathrm{M})$ compared with the OATP1B1-knockdown cells (Fig. 5B) clearly demonstrating that OATP1B1 expression is associated with cytotoxicity. 
Table II. Michaelis-Menten parameters of curcumin and tetrahydrocurcumin determined in ZR-75-1 and OATP1B1-knockdown ZR-75-1 cells.

\begin{tabular}{|c|c|c|c|c|}
\hline \multirow[b]{2}{*}{ Substrate } & \multicolumn{2}{|c|}{ ZR-75-1 } & \multicolumn{2}{|c|}{ OATP1B1-knockdown ZR-75-1 } \\
\hline & $\mathrm{K}_{\mathrm{m}}[\mu \mathrm{M}]$ & $\mathrm{V}_{\max }[\mathrm{pmol} / \mathrm{mg} / \mathrm{min}]$ & $\mathrm{K}_{\mathrm{m}}[\mu \mathrm{M}]$ & $\mathrm{V}_{\max }[\mathrm{pmol} / \mathrm{mg} / \mathrm{min}]$ \\
\hline Curcumin & $85.1 \pm 9.1^{\mathrm{a}}$ & $3535 \pm 342^{\mathrm{a}}$ & $56.7 \pm 5.8^{\mathrm{a}}$ & $1741 \pm 122^{\mathrm{a}}$ \\
\hline TH-cur & $44.7 \pm 7.9$ & $7904 \pm 420^{\mathrm{a}}$ & $69.6 \pm 14.8$ & $4201 \pm 337^{\mathrm{a}}$ \\
\hline
\end{tabular}

Values are presented as the means \pm SD of 3 individual determinations. Kinetic parameters were calculated by fitting the data to the Michaelis-Menten $\left(\mathrm{K}_{\mathrm{m}}\right)$ equation with non-linear regression. ${ }^{\mathrm{a}} \mathrm{K}_{\mathrm{m}}$ and $\mathrm{V}_{\max }$ values in bold and marked with an asterisk are significantly different $(\mathrm{P}<0.05)$ between wild-type and OATP1B1-knockdown ZR-75-1 cells. TH-cur, tetrahydrocurcumin .

\section{A}

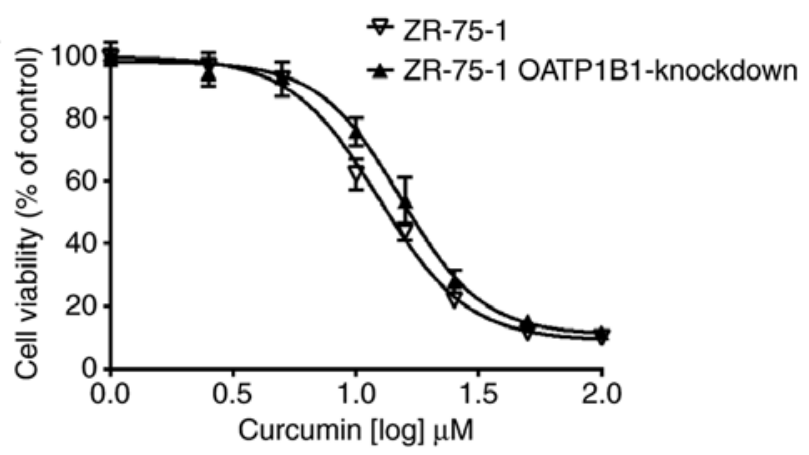

B

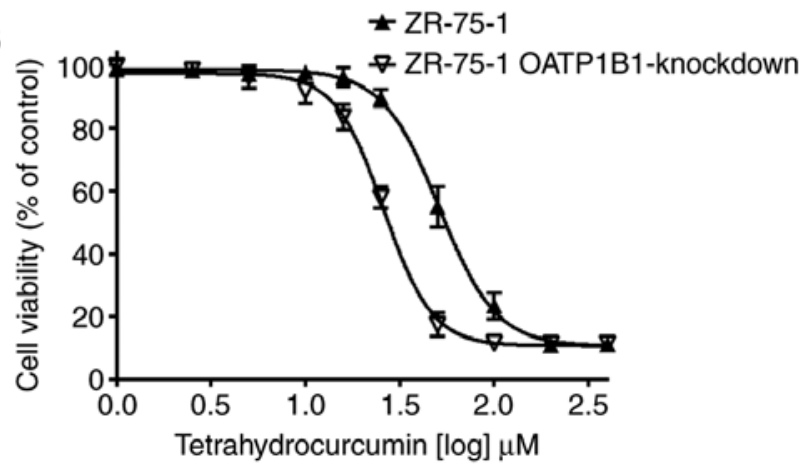

Figure 5. Cytotoxicity of (A) curcumin and (B) tetrahydrocurcumin to ZR-75-1 and OATP1B1-knockdown ZR-75-1 cells. After incubation of 50,000 cells for $72 \mathrm{~h}$ with $2.5-100 \mu \mathrm{M}$ curcumin at $37^{\circ} \mathrm{C}$, the number of viable cells were determined. Dose response curves were obtained by non-linear curve fitting using GraphPad Prism 6.0 software (GraphPad Software, Inc.). The data represent the mean $\pm \mathrm{SD}$ of three individual determinations. OATP, organic anion-transporting polypeptide.

Inhibition of $N F-\kappa B$-luciferase by curcumin in wild-type and OATP1B1-knockdown ZR-75-1 cells. To further evaluate the OATP1B1-dependent differences in the activity of curcumin, wild-type and OATP1B1-knockdown ZR-75-1 cells were simultaneously transfected with an NF- $\mathrm{NB}$ promoter sequence connected to a luciferase reporter. Prior to $N F-\kappa B$ reporter induction by $10 \mathrm{ng} / \mathrm{ml} \mathrm{IL-1} \beta$ for $90 \mathrm{~min}$, cells were treated with curcumin or BAY11-7082 for $30 \mathrm{~min}$, and the luciferase signals were assessed. As revealed in Fig. 6, curcumin significantly inhibited IL- $1 \beta$-induced $N F-\kappa B$ reporter expression by $40.1 \pm 7.78 \%$ in wild-type and by $30.9 \pm 10.1 \%$ in OATP1B1-knockdown cells. Notably, curcumin was almost as potent as the known NF- $\mathrm{B}$ inhibitor BAY11-7082, used as a positive control $(71.3 \pm 12.9$ and $62.8 \pm 5.3 \%$ inhibition in

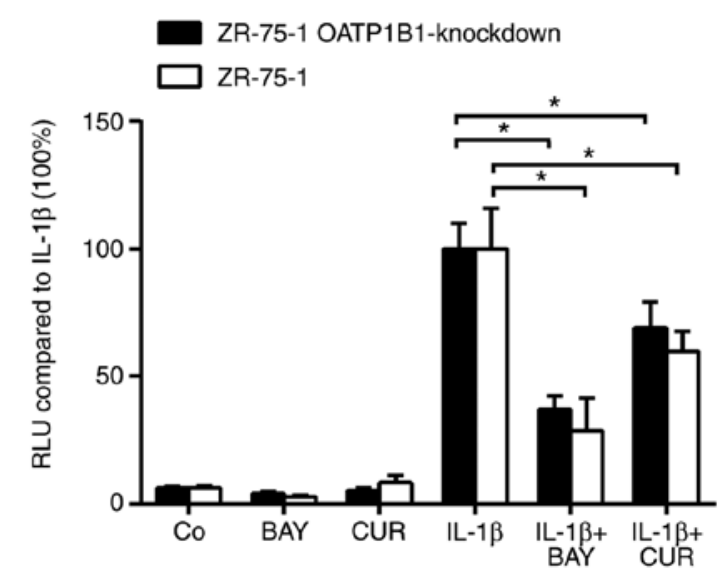

Figure 6. Inhibition of NF- $\mathrm{B}$ activity by curcumin. A total of 100,000 ZR-75-1 wild-type and ZR-75-1 OATP1B1-knockdown cells were seeded in 24-well plates and allowed to grow to $70 \%$ confluence. Cells were then pre-treated with $10 \mu \mathrm{M}$ BAY or $100 \mu \mathrm{M}$ CUR for $30 \mathrm{~min}$ or with solvent (DMSO). Thereafter, where indicated, cells were stimulated with IL-1 $\beta$ (10 $\mathrm{ng} / \mathrm{ml}$ for $90 \mathrm{~min}$ ), when cells were lysed and firefly luciferase activity was determined, which was normalized to Renilla luciferase activity (measured subsequently; RLU, relative light unit). Experiments were performed in triplicate, error bars indicate \pm SD and asterisks denote significance between the IL-1 $\beta$-induced positive controls and the IL-1 $\beta$-induced BAY and CUR treatment groups. OATP, organic anion-transporting polypeptide; Co, control; CUR, curcumin; BAY, Bay11-7082.

wild-type and in the OATP-knockdown clone, respectively). As anticipated inhibition of NF- $\mathrm{NB}$-luciferase by curcumin in OATP1B1-knockdown cells was less pronounced compared with wild-type cells. However, differences were not significant.

\section{Discussion}

The present study aimed to determine the kinetics of the cellular uptake of curcumin and its major metabolites curcumin sulfate, curcumin glucuronide and tetrahydrocurcumin and Chinese hamster ovary $(\mathrm{CHO})$ cells stably transfected with the three-major organic anion-transporting polypeptides (OATPs) were used. As indicated in Fig. 1 and Table I, curcumin displayed saturable uptake kinetics for OATP1B1, OATP1B3 and OATP2B1 with similar $\mathrm{K}_{\mathrm{m}}$ values (ranging from 46.9 to $51.9 \mu \mathrm{M}$ ) which indicates high affinity for the transporter. The affinity of curcumin sulfate was in a similar range for OATP2B1 but was higher for OATP1B3 and OATP1B1 
( $\mathrm{K}_{\mathrm{m}}$ values, 50.0, 67.7 and $89.1 \mu \mathrm{M}$, respectively). Notably, tetrahydrocurcumin was only transported by OATP1B1 and OATP1B3 with reduced affinity in the case of OATP1B1 $\left(\mathrm{K}_{\mathrm{m}}\right.$, $83.7 \mu \mathrm{M})$ and increased affinity $\left(\mathrm{K}_{\mathrm{m}}, 38.6 \mu \mathrm{M}\right)$ in the case of OATP1B3. Curcumin glucuronide was not transported by any of these OATPs. Notably, OATP-dependent uptake was compound-specific. While the transport capacity $\left(\mathrm{V}_{\max } / \mathrm{K}_{\mathrm{m}}\right)$ for curcumin sulfate was low for all three OATPs $(0.51$, 0.50 and $0.48 \mu \mathrm{l} / \mathrm{min} / \mathrm{mg}$ protein, respectively), the uptake of curcumin by OATP1B1, OATP1B3 and OATP2B1-transfected cells was 6.3-, 8.7- and 13.7-fold higher, respectively. The uptake of tetrahydrocurcumin by OATP1B1 was even more pronounced (i.e. 44.3-fold higher compared with curcumin). These data revealed that OATP1B1 could be the most important transporter for tetrahydrocurcumin uptake, whereas the three OATPs were equally important for the cellular uptake of curcumin and curcumin sulfate. The involvement of OATP1B1, OAT1B3 and OATP2B1 in the uptake of curcumin was in line with the data from Zhou et al (28) which also demonstrated that this compound was a substrate of all three transporters. However, contrary to that study, the present study could not confirm any OATP-dependent uptake of curcumin glucuronide. Based on our data, it is not possible to predict the contribution of OATP2B1 in the gut, for that of OATP1B1, OATP1B3 and OATP2B1 in the liver, to the overall uptake of curcumin and its major metabolites in humans due to large inter individual variability (up to 10 -fold differences) in OATP protein levels (36-38).

Our data also suggested that unconjugated curcumin and tetrahydrocurcumin concentrations in human blood were lower than the $\mathrm{K}_{\mathrm{m}}$ values calculated for their uptake by ZR-75-1 cells. A recent phase-I study revealed that administration of liposomal curcumin at $300 \mathrm{mg} / \mathrm{m}^{2}$ over $8 \mathrm{~h}$ to patients with metastatic cancer resulted in maximal plasma concentrations of up to $3.48 \mu \mathrm{g} / \mathrm{ml}(9.45 \mu \mathrm{M})(39)$. Peak plasma concentrations of up to $22 \mu \mathrm{M}$ were observed for tetrahydrocurcumin in rats following an oral dose of $500 \mathrm{mg} / \mathrm{kg}$ tetrahydrocurcumin (40). Notably, the total tissue concentrations of conjugates (curcumin sulfate and curcumin glucuronide) were much higher than their blood levels in mice $1 \mathrm{~h}$ after i.p. administration of curcumin $(0.1 \mathrm{~g} / \mathrm{kg})$ leading to concentrations of 26.1 $\mu \mathrm{g} / \mathrm{g}(52.6 \mu \mathrm{M}), 26.9 \mu \mathrm{g} / \mathrm{g}(54.3 \mu \mathrm{M})$ and $117 \mu \mathrm{g} / \mathrm{g}(236 \mu \mathrm{M})$ in the spleen, liver and intestine, respectively (41).

To determine the importance of OATPs in the uptake of curcumin and tetrahydrocurecumin, hormone-dependent ZR-75-1 breast cancer cells which express high levels of OATP1B1, but do not express OATP1B3 or OATP2B1 (27), were incubated with both compounds. The uptake of curcumin by the ZR-75-1 OATP1B1-knockdown cells was significantly decreased compared with wild-type cells leading to lower $\mathrm{V}_{\max }$ values (Fig. 4 and Table II). Notably, differences in curcumin uptake were only observed at $>100 \mu \mathrm{M}$ curcumin concentrations and not expected based on the uptake experiments in OATP-transfected CHO cells. This may be explained by the rapid non-enzymatic hydrolysis of curcumin at $\mathrm{pH}$ 7.4, particularly at low curcumin concentrations, mainly forming ferulic acid, feruloyl methan and vanillin. These degradation products were stable under physiological conditions and exhibited antitumor properties against various cancer cell lines (42-44). Whether these compounds are substrates for OATPs or other not identified uptake transporters is not yet known. Compared with curcumin, the uptake of tetrahydrocurcumin was significantly different at all the measured concentrations in wild-type and OATP1B1-knockdown cells, probably due to the higher stability of tetrahydrocurcumin at physiological $\mathrm{pH}$ (21). Differences in the cellular uptake of tetrahydrocurcumin also resulted in higher $K_{m}$ values in OATP1B1-knockdown cells indicating a lower affinity for this transporter, albeit the results were not statistically significant.

Concomitant with the reduced uptake displayed by ZR-75-1 OATP1B1 knockdown cells, the present study also observed a higher $\mathrm{IC}_{50}$ value for curcumin in the cytotoxicity assay compared with OATP1B1-expressing wild-type cells (15.2 vs. $12.4 \mu \mathrm{M}$; Fig. 5), although this difference was not statistically significant and may be explained by the degradation of curcumin in the medium and probably also in the cytoplasm. For the more stable tetrahydrocurcumin, however, the difference observed in the $\mathrm{IC}_{50}$ value between wild-type and OATP1-knockdown ZR-75-1 cells was statistically significant. Specifically, the $\mathrm{IC}_{50}$ value was reduced in the OATP1B1-expressing cells (26.0 vs. $51.3 \mu \mathrm{M})$ indicating an association between OATP1B1 expression and cytotoxicity. The decreased uptake of curcumin by the ZR-75-1 OATP1B1-knockdown cells also resulted in a reduced inhibition of IL-1 $\beta$-activated NF- $\kappa$ B reporter expression (Fig. 6), which was not significant possibly again due to non-enzymatic hydrolysis of curcumin to ferulic acid, feruloyl methan and vanillin in the medium. Formation of these pharmacologically active degradation products may therefore contribute, in combination with tetrahydrocurcumin and curcumin sulfate, to the anticancer properties of curcumin in vitro and in vivo. Since NF- $\kappa \mathrm{B}$ is highly expressed in breast cancer, thereby facilitating growth and progression (45), administration of curcumin, either as a single compound or in combination with anticancer drugs, may lead to cancer chemoprevention as revealed in human studies $(45,46)$.

Different cellular expression levels of OATPs may greatly affect the uptake of curcumin sulfate and tetrahydrocurcumin, and to lesser extent also curcumin, by tumor cells, thereby altering the efficacy of these compounds. Patients with little or no detectable expression of OATP1B1, OATP1B3 and OATP2B1 may, as a result exhibit decreased response rates to curcumin and its primary metabolites. The same occurs when curcumin and tetrahydrocurcumin are concomitantly administered with OATP inhibitors such as clarithromycin, erythromycin and roxithromycin which inhibit the intake of pravastatin in OATP1B1- and OATP1B3-transfected 293 cells (37). Cyclosporin A is a potent inhibitor of both OATPs leading to decreased uptake rates of bosentan (31) and fexofenadine (47) in 293 and CHO cells. Several natural occurring flavonoids inhibit OATP-dependent uptake as revealed for dehydroepiandrosterone sulfate in a cellular model (48). Whether other transporters such OATP2A1 and OATP4C1, which are expressed in ZR-75-1 wild-type cells (24), are also involved in the uptake of curcumin and its main metabolites is not yet known. Other potential candidates may be the organic anion transporters (OATs) which are involved in the transport of polyphenol glucuronides and sulfates $(49,50)$. In fact, Zhou et al reported, at least for curcumin and curcumin glucuronide uptake, the involvement of OAT1 and OAT3 (28). Our 
data did not demonstrate any passive diffusion mechanism responsible for the uptake of curcumin, curcumin sulfate, or tetrahydrocurcumin since the uptake kinetics in wild-typeand OATP1B1-knockdown ZR-75-1 cells was saturable, indicating protein-mediated transport. However, the involvement of cellular efflux mechanism in ZR-75-1 breast cancer cells cannot be excluded, since uptake and efflux transport works in concert.

In conclusion, our results demonstrated that curcumin, curcumin sulfate and tetrahydrocurcumin, but not curcumin glucuronide, are substrates of various OATPs as demonstrated in OATP-transfected CHO cells. The increased mRNA levels of OATP1B1 in wild-type human breast cancer ZR-75-1 cells compared with OATP1B1-knockdown cells were associated with a higher initial uptake of curcumin and tetrahydrocurcumin leading to decreased $\mathrm{IC}_{50}$ values. This may occur in patients following the intravenous application of curcumin and tetrahydrocurcumin as anticancer agents. Future clinical studies should determine not only the concentration of curcumin, its main degradation products and metabolites in blood and tumors but also the expression levels of OATPs.

\section{Acknowledgements}

Not applicable.

\section{Funding}

QAJ received a fellowship from OeAD, Austria, in collaboration with the Higher Education Commission of Pakistan. NJ was awarded a scholarship financed by the Royal Golden Jubilee Ph.D. Program of Thailand.

\section{Availability of data and materials}

All data generated or analysed during this study are included in this published article.

\section{Authors' contributions}

NJ performed the experiments and analyzed the data (uptake experiments, cytotoxicity and statistical analysis). QAJ collected analysed and interpreted the data (uptake experiments and cytotoxicity). JR designed and supervised the uptake experiments. DM performed and interpreted the NF- $\kappa \mathrm{B}$ experiments. GK wrote the section concerning $N F-\kappa B$ and interpreted the data. BS was involved in the study conception, interpretation of data and proofreading of the manuscript. KJ interpreted the data concerning the uptake experiments and was involved in the proofreading of the manuscript. WJ interpreted the data, wrote and edited the manuscript. All authors read and approved the final manuscript.

\section{Ethics approval and consent to participate}

Not applicable.

\section{Patient consent for publication}

Not applicable.

\section{Competing interests}

The authors declare that they have no competing interests.

\section{References}

1. Pan MH, Chiou YS, Chen LH and Ho CT: Breast cancer chemoprevention by dietary natural phenolic compounds: Specific epigenetic related molecular targets. Mol Nutr Food Res 59: 21-35, 2015.

2. Aqil F, Jeyabalan J, Munagala R, Ravoori S, Vadhanam MV, Schultz DJ and Gupta RC: Chemoprevention of rat mammary carcinogenesis by Apiaceae spices. Int J Mol Sci 18: E425, 2017.

3. Hatcher H, Planalp R, Cho J, Torti FM and Torti SV: Curcumin: From ancient medicine to current clinical trials. Cell Mol Life Sci 65: 1631-1652, 2008.

4. Bimonte S, Barbieri A, Palma G, Rea D, Luciano A, D'Aiuto $\mathrm{M}$, Arra C and Izzo F: Dissecting the role of curcumin in tumor growth and angiogenesis in a mouse model of human breast cancer. Biomed Res Int 2015: 878134, 2015.

5. Lv ZD, Liu XP, Zhao WJ, Dong Q, Li FN, Wang HB and Kong $\mathrm{B}$ : Curcumin induces apoptosis in breast cancer cells and inhibits tumor growth in vitro and in vivo. Int J Clin Exp Pathol 7: 2818-2824, 2014.

6. Wang Y, Yu J, Cui R, Lin J and Ding X: Curcumin in treating breast cancer: A review. J Lab Autom 21: 723-731, 2016.

7. Kumar G, Mittal S, Sak K and Tuli HS: Molecular mechanisms underlying chemopreventive potential of curcumin: Current challenges and future perspectives. Life Sci 148: 313-328, 2016.

8. Bachmeier BE, Nerlich AG, Iancu CM, Cilli M, Schleicher E, Vené R, Dell'Eva R, Jochum M, Albini A and Pfeffer U: The chemopreventive polyphenol Curcumin prevents hematogenous breast cancer metastases in immunodeficient mice. Cell Physiol Biochem 19: 137-152, 2007.

9. Quispe-Soto ET and Calaf GM: Effect of curcumin and paclitaxel on breast carcinogenesis. Int J Oncol 49: 2569-2577, 2016.

10. Bayet-Robert M, Kwiatkowski F, Leheurteur M, Gachon F, Planchat E, Abrial C, Mouret-Reynier MA, Durando X, Barthomeuf $\mathrm{C}$ and Chollet P: Phase I dose escalation trial of docetaxel plus curcumin in patients with advanced and metastatic breast cancer. Cancer Biol Ther 9: 8-14, 2010.

11. Ireson C, Orr S, Jones DJ, Verschoyle R, Lim CK, Luo JL, Howells L, Plummer S, Jukes R, Williams M, et al: Characterization of metabolites of the chemopreventive agent curcumin in human and rat hepatocytes and in the rat in vivo, and evaluation of their ability to inhibit phorbol ester-induced prostaglandin E2 production. Cancer Res 61: 1058-1064, 2001.

12. Sharma RA, McLelland HR, Hill KA, Ireson CR, Euden SA, Manson MM, Pirmohamed M, Marnett LJ, Gescher AJ and Steward WP: Pharmacodynamic and pharmacokinetic study of oral Curcuma extract in patients with colorectal cancer. Clin Cancer Res 7: 1894-1900, 2001.

13. Prasad S, Tyagi AK and Aggarwal BB: Recent developments in delivery, bioavailability, absorption and metabolism of curcumin: The golden pigment from golden spice. Cancer Res Treat 46: 2-18, 2014.

14. Stanić Z: Curcumin, a compound from natural sources, a true scientific challenge-a review. Plant Foods Hum Nutr 72: 1-12, 2017.

15. Jamil QUA, Jaerapong N, Zehl M, Jarukamjorn K and Jäger W: Metabolism of curcumin in human breast cancer cells: Impact of sulfation on cytotoxicity. Planta Med 83: 1028-1034, 2017.

16. Tian Y, Bian Y, Jiang Y, Qian S, Yu A and Zeng S: Interplay of breast cancer resistance protein (BCRP) and metabolizing enzymes. Curr Drug Metab 16: 877-893, 2015.

17. Ebert B, Seidel A and Lampen A: Phytochemicals induce breast cancer resistance protein in Caco-2 cells and enhance the transport of benzo[a]pyrene-3-sulfate. Toxicol Sci 96: 227-236, 2007.

18. Liu W, Zhang Z, Lin G, Luo D, Chen H, Yang H, Liang J, Liu $\mathrm{Y}, \mathrm{Xie} \mathrm{J}, \mathrm{Su} \mathrm{Z}$, et al: Tetrahydrocurcumin is more effective than curcumin in inducing the apoptosis of $\mathrm{H} 22$ cells via regulation of a mitochondrial apoptosis pathway in ascites tumor-bearing mice. Food Funct 8: 3120-3129, 2017.

19. Lai CS, Wu JC, Yu SF, Badmaev V, Nagabhushanam K, Ho $\mathrm{CT}$ and Pan MH: Tetrahydrocurcumin is more effective than curcumin in preventing azoxymethane-induced colon carcinogenesis. Mol Nutr Food Res 55: 1819-1828, 2011. 
20. Zhang ZB, Luo DD, Xie JH, Xian YF, Lai ZQ, Liu YH, Li WH, Chen JN, Lai XP, Lin ZX, et al: Curcumin's metabolites, tetrahydrocurcumin and octahydrocurcumin, possess superior anti-inflammatory effects in vivo through suppression of TAK1-NF- $\kappa$ B pathway. Front Pharmacol 9: 1181, 2018.

21. Aggarwal BB, Deb L and Prasad S: Curcumin differs from tetrahydrocurcumin for molecular targets, signaling pathways and cellular responses. Molecules 20: 185-205, 2014.

22. Hagenbuch B and Gui C: Xenobiotic transporters of the human organic anion transporting polypeptides (OATP) family. Xenobiotica 38: 778-801, 2008.

23. Kim RB: Organic anion-transporting polypeptide (OATP) transporter family and drug disposition. Eur J Clin Invest 33 (Suppl 2): S1-S5, 2003.

24. Gui C, Obaidat A, Chaguturu R and Hagenbuch B: Development of a cell-based high-throughput assay to screen for inhibitors of organic anion transporting polypeptides 1B1 and 1B3. Curr Chem Genomics 4: 1-8, 2010.

25. Obaidat A, Roth $M$ and Hagenbuch B: The expression and function of organic anion transporting polypeptides in normal tissues and in cancer. Annu Rev Pharmacol Toxicol 52: 135-151, 2012.

26. Svoboda M, Riha J, Wlcek K, Jaeger W and Thalhammer T: Organic anion transporting polypeptides (OATPs): Regulation of expression and function. Curr Drug Metab 12: 139-153, 2011.

27. Wlcek K, Svoboda M, Thalhammer T, Sellner F, Krupitza G and Jaeger W: Altered expression of organic anion transporter polypeptide (OATP) genes in human breast carcinoma. Cancer Biol Ther 7: 1450-1455, 2008.

28. Zhou X, Zhang F, Chen C, Guo Z, Liu J, Yu J, Xu Y, Zhong D and Jiang H: Impact of curcumin on the pharmacokinetics of rosuvastatin in rats and dogs based on the conjugated metabolites. Xenobiotica 47: 267-275, 2017

29. Sun X, Li J, Guo C, Xing H, Xu J, Wen Y, Qiu Z, Zhang Q, Zheng Y, Chen X, et al: Pharmacokinetic effects of curcumin on docetaxel mediated by OATP1B1, OATP1B3 and CYP450s. Drug Metab Pharmacokinet 31: 269-275, 2016.

30. Gui C, Miao Y, Thompson L, Wahlgren B, Mock M, Stieger $\mathrm{B}$ and Hagenbuch B: Effect of pregnane $\mathrm{X}$ receptor ligands on transport mediated by human OATP1B1 and OATP1B3. Eur J Pharmacol 584: 57-65, 2008.

31. Treiber A, Schneiter R, Häusler S and Stieger B: Bosentan is a substrate of human OATP1B1 and OATP1B3: Inhibition of hepatic uptake as the common mechanism of its interactions with cyclosporin A, rifampicin, and sildenafil. Drug Metab Dispos 35: 1400-1407, 2007

32. Leuthold S, Hagenbuch B, Mohebbi N, Wagner CA, Meier PJ and Stieger B: Mechanisms of $\mathrm{pH}$-gradient driven transport mediated by organic anion polypeptide transporters. Am J Physiol Cell Physiol 296: C570-C582, 2009.

33. Brenner S, Riha J, Giessrigl B, Thalhammer T, Grusch M, Krupitza G, Stieger B and Jäger W: The effect of organic anion-transporting polypeptides $1 \mathrm{~B} 1,1 \mathrm{~B} 3$ and $2 \mathrm{~B} 1$ on the antitumor activity of flavopiridol in breast cancer cells. Int $\mathbf{J}$ Oncol 46: 324-332, 2015.

34. Livak KJ and Schmittgen TD: Analysis of relative gene expression data using real-time quantitative PCR and the $2^{-{ }^{-\Delta \Delta C} \mathrm{~T}}$ method. Methods 25: 402-408, 2001.

35. Palermo DP, DeGraaf ME, Marotti KR, Rehberg E and Post LE: Production of analytical quantities of recombinant proteins in Chinese hamster ovary cells using sodium butyrate to elevate gene expression. J Biotechnol 19: 35-47, 1991.

36. Otsuka S, Schaefer O, Kawakami H, Inoue T, Lehner S, Saito A, Ishiguro N, Kishimoto W, Ludwig-Schwellinger E, Ebner $\mathrm{T}$, et al: Simultaneous absolute protein quantification of transporters, cytochromes P450, and UDP-glucuronosyltransferases as a novel approach for the characterization of individual human liver: Comparison with mRNA levels and activities. Drug Metab Dispos 40: 83-92, 2012.
37. Prasad B, Evers R, Gupta A, Hop CE, Salphati L, Shukla S, Ambudkar SV and Unadkat JD: Interindividual variability in hepatic organic anion-transporting polypeptides and P-glycoprotein (ABCB1) protein expression: Quantification by liquid chromatography-tandem mass spectroscopy and influence of genotype, age, and sex. Drug Metab Dispos 42: 78-88, 2014.

38. Nies AT, Niemi M, Burk O, Winter S, Zanger UM, Stieger B, Schwab M and Schaeffeler E: Genetics is a major determinant of expression of the human hepatic uptake transporter OATP1B1, but not of OATP1B3 and OATP2B1. Genome Med 5: 1, 2013.

39. Greil R, Greil-Ressler S, Weiss L, Schönlieb C, Magnes T, Radl B, Bolger GT, Vcelar B and Sordillo PP: A phase 1 dose-escalation study on the safety, tolerability and activity of liposomal curcumin (Lipocurc ${ }^{\mathrm{TM}}$ ) in patients with locally advanced or metastatic cancer. Cancer Chemother Pharmacol 82: 695-706, 2018.

40. Novaes JT, Lillico R, Sayre CL, Nagabushnam K, Majeed M, Chen Y, Ho EA, Oliveira ALP, Martinez SE, Alrushaid S, et al: Disposition, metabolism and histone deacetylase and acetyltransferase inhibition activity of tetrahydrocurcumin and other curcuminoids. Pharmaceutics 9: E45, 2017.

41. Pan MH, Huang TM and Lin JK: Biotransformation of curcumin through reduction and glucuronidation in mice. Drug Metab Dispos 27: 486-494, 1999.

42. Celińska-Janowicz K, Zaręba I, Lazarek U, Teul J, Tomczyk M, Pałka J and Miltyk W: Constituents of propolis: Chrysin, caffeic acid, p-coumaric acid, and ferulic acid induce PRODH/POX-dependent apoptosis in human tongue squamous cell carcinoma cell (CAL-27). Front Pharmacol 9: 336, 2018.

43. Pavelyev RS, Bondar OV, Nguyen TNT, Ziganshina AA, Al Farroukh M, Karwt R, Alekbaeva GD, Pugachev MV, Yamaleeva $\mathrm{ZR}$, Kataeva ON, et al: Synthesis and in vitro antitumor activity of novel alkenyl derivatives of pyridoxine, bioisosteric analogs of feruloyl methane. Bioorg Med Chem 26: 5824-5837, 2018.

44. Elsherbiny NM, Younis NN, Shaheen MA and Elseweidy MM: The synergistic effect between vanillin and doxorubicin in ehrlich ascites carcinoma solid tumor and MCF-7 human breast cancer cell line. Pathol Res Pract 212: 767-777, 2016.

45. Wang W, Nag SA and Zhang R: Targeting the NFkB signaling pathways for breast cancer prevention and therapy. Curr Med Chem 22: 264-289, 2015.

46. Sen GS, Mohanty S, Hossain DM, Bhattacharyya S, Banerjee S, Chakraborty J, Saha S, Ray P, Bhattacharjee P, Mandal D, et al: Curcumin enhances the efficacy of chemotherapy by tailoring p65NFkB-p300 cross-talk in favor of p53-p300 in breast cancer. J Biol Chem 286: 42232-42247, 2011.

47. Matsushima S, Maeda K, Ishiguro N, Igarashi T and Sugiyama $\mathrm{Y}$ : Investigation of the inhibitory effects of various drugs on the hepatic uptake of fexofenadine in humans. Drug Metab Dispos 36: 663-669, 2008

48. Wang X, Wolkoff AW and Morris ME: Flavonoids as a novel class of human organic anion-transporting polypeptide OATP1B1 (OATP-C) modulators. Drug Metab Dispos 33: 1666-1672, 2005.

49. Wong CC, Botting NP, Orfila C, Al-Maharik N and Williamson G: Flavonoid conjugates interact with organic anion transporters (OATs) and attenuate cytotoxicity of adefovir mediated by organic anion transporter 1 (OAT1/SLC22A6). Biochem Pharmacol 81: 942-949, 2011.

50. Wong CC, Akiyama Y, Abe T, Lippiat JD, Orfila C and Williamson G: Carrier-mediated transport of quercetin conjugates: Involvement of organic anion transporters and organic anion transporting polypeptides. Biochem Pharmacol 84: 564-570, 2012 